\title{
PENGARUH KUALITAS PEPELAYANAN DAN KINERJA PEGAWAI TERHADAP KEPUASAN MASYARAKAT (Keluarganya Warga Binaan Pemasyarakatan) PADA LEMBAGA PEMASYARAKATAN KELAS IIB SLAWI
}

\author{
Edi Sutrisno dan Joko Maryono \\ Lapas Slawi, dan Universitas Pancasakti Tegal \\ Email : eddy.sutrisno39@gmail.com
}

\begin{abstract}
This research is called the influence of the quality of services and performance employees to of community satisfaction his people residents under the jurisdiction of correctional in a correctional institution class IIB slawi. Based on a title in on the research aims to understand: 1 . Know the influence of the quality of service for of community satisfaction his people residents under the jurisdiction of correctional in a correctional institution class iib slawi. 2. Know the influence of performance employees to of community satisfaction his people residents under the jurisdiction of correctional in a correctional institution class iib slawi. 3. Know the influence of the quality of services and performance employees to of community satisfaction his people residents under the jurisdiction of correctional in a correctional institution class IIB slawi. Research methodology used in this research is the method observation, interview, the questionnaire, and study literature, technique the sample non probability of sampling by using scale likert and methods the determination of sample used is convenience / accidental sampling as many as 171 sample.The method of analysis the data used is the method linear regression multiple ( multi linear regression). The results of the study in partial shows that 1). The quality of services $(x 1)$ and performance employees ( $x 2$ in together have had a positive impact and significant impact on of community satisfaction his people residents under the jurisdiction of correctional) ( $y$ in a correctional institution class IIB Slawi. 2). The quality of services (xl in partial have had a positive impact and significant impact on of community satisfaction his people residents under the jurisdiction of correctional) (y in a correctional institution class iib slawi. 3). Performance employees ( $x 2$ in partial have had a positive impact and significant impact on satisfaction masyarakan his people residents under the jurisdiction of correctional) (y in a correctional institution class IIB Slawi).
\end{abstract}

Keyword: the quality of services, performance employees, of community satisfaction

\section{PENDAHULUAN}

Aparatur pemerintah sebagai abdi negara dan abdi masyarakat mempunyai tugas pokok diantaranya penyelenggaraan tugas umum pemerintah, pembangunan dan pelaksanaan pelayanan kepada masyarakat. Pemerintahan modern menurut Rasyid (1997:11) pada hakekatnya adalah pelayanan kepada masyarakat, dengan kata lain, ia tidak diadakan untuk melayani dirinya sendiri, tetapi untuk melayani masyarakat serta menciptakan kondisi yang memungkinkan setiap anggota masyarakat mengembangkan kemampuan dan kreativitasnya demi tercapainya tujuan bersama. Pelayanan publik dapat dinyatakan sebagai segala bentuk pelayanan sektor publik yang dilaksanakan oleh aparatur 
pemerintah dalam bentuk berupa barang dan jasa, yang sesuai dengan kebutuhan masyarakat dan ketentuan peraturan perundang-undangan yang berlaku (sianipar, 1995:5).

Tugas pemerintahan dalam rangka penyelenggaraan pelayanan publik yaitu sebagai fungsi umum pemerintahan yang meliputi pendayagunaan kelembagaan, kepegawaian, dan ketatalaksanaan. Sedangkan dalam rangka pelaksanaan tugas pembangunan tertentu dilakukan melalui pembangunan bangsa (cultural and political development) serta melalui pembangunan ekonomi dan sosial (economic and social development) yang diarahkan meningkatkan kesejahteraan dan kemakmuran seluruh masyarakat.

Menjalankan tugas pelayanan publik kepada masyarakat, tugas pemerintahan, dan tugas pembangunan tertentu, ASN harus memiliki profesi dan manajemen ASN yang berdasarkan pada sistem merit atau perbandingan antara kualifikasi, kompetensi, dan kinerja yang dibutuhkan oleh jabatan dengan kualifikasi, kompetensi, dan kinerja yang dimiliki oleh calon ASN dalam rekrutmen, pengangkatan, penempatan, dan promosi jabatan secara terbuka dan kompetitif, sejalan dengan tata kelola pemerintahan yang baik.

Pelayanan publik oleh aparatur pemerintah dewasa ini masih banyak dijumpai kelemahan sehingga belum dapat memenuhi kualitas yang diharapkan masyarakat. Hal ini ditandai masih adanya berbagai keluhan masyarakat yang disampaikan melalui media massa, sehingga dapat menimbulkan citra yang kurang baik terhadap aparatur pemerintah. Mengingat fungsi utama pemerintah adalah melayani masyarakat maka pemerintah perlu terus meningkatkan kualitas pelayanan kepada masyarakat.
Penyelenggaraan pelayanan publik oleh instansi pemerintah dalam rangka memenuhi tuntutan kebutuhan masyarakat sebagai akibat kemajuan ekonomi dan pelayanan yang lebih nyaman, penyelenggara dapat menyediakan pelayanan berjenjang dengan mempertimbangkan proporsionalitas dan kebutuhan masyarakat, agar tidak menimbulkan diskriminasi dengan tetap menjunjung tinggi prinsip-prinsip keadilan, serta tidak mengurangi kualitas pelayanan bagi masyarakat pada umumnya.

Peran serta masyarakat dalam penyelenggaraan pelayanan publik diperlukan untuk menjamin pelayanan secara transparan, akuntabel serta sesuai dengan kebutuhan yang diharapkan oleh masyarakat. Penyusunan standar pelayanan tidak hanya dalam bentuk peran serta secara aktif, tetapi juga dengan pengawasan, evaluasi penerapan standar, evaluasi kinerja, pemberian penghargaan, serta penyusunan kebijakan pelayanan publik.

Salah satu upaya untuk meningkatkan kualitas pelayanan publik, sebagaimana diamanatkan dalam Undang-Undang Republik Indonesia Nomor: 25 Tahun 2000 Tentang Program Pembangunan Nasional (PROPENAS), perlu disusun indeks kepuasan masyarakat sebagai tolak ukur untuk menilai tingkat kualitas pelayanan. Di samping itu data indeks kepuasan masyarakat akan dapat menjadi bahan penilaian terhadap unsur pelayanan yang masih perlu diperbaiki guna menjadi pendorong setiap unit penyelenggara pelayanan publik untuk meningkatkan kualitas pelayanannya.

Pentingnya penyelenggaraan pelayanan publik yang baik dan memuaskan, menjadi perhatian utama pemerintah di era sekarang ini. Dwiyanto (2003:81) menyebut kinerja pelayanan publik menjadi salah satu dimensi yang strategis dalam menilai 
keberhasilan dalam pelaksanan otonomi daerah dan reformasi tata pemerintahan. Semakin tinggi kepedulian Lembaga atau organisasi instansi pemerintah terhadap tata pemerintah yang baik (good governance), kinerja pelayanan publik semakin baik. Wajar jika kinerja pelayanan publik kemudian digunakan untuk mengamati kinerja instansi pemerintah dalam hal ini Lembaga Pemasyarakatan Kelas IIB Slawi.

\section{Menurut Undang-Undang}

Nomor: 12 Tahun 1995 Tentang Pemasyarakatan pasal 1 ayat 3 menyebutkan bahwa Lembaga Pemasyarakatan yang selanjutnya disebut LAPAS adalah tempat untuk melaksanakan pembinaan narapidana dan anak didik pemasyarakatan. Lembaga Pemasyarakatan Kelas IIB Slawi adalah Unit Pelaksana Teknis Pemasyarakatan di bawah Kantor Wilayah Kementerian Hukum dan Hak Asasi Manusia Jawa Tengah. Merupakan salah satu instansi pelayanan publik di bidang pelayanan terhadap Warga Binaan Pemasyarakatan.

Secara umum, yang dimaksud kepuasan adalah perasaan senang atau kecewa seseorang yang muncul setelah membandingkan antara kinerja produk dengan hasil yang diinginkan (Kotler, 2005). Jika kualitas pelayanan melebihi harapan, maka pelanggan/konsumen akan merasa amat puas. Sedangkan Jacobalis (dalam Supraptono, 1998) menyatakan bahwa kepuasan adalah rasa lega atau senang karena harapan tentang sesuatu telah terpenuhi.

Pendapat di atas disimpulkan bahwa kepuasan adalah tingkat perasaan seseorang setelah membandingkan kinerja yang dirasakan dengan harapan. Sedangkan kepuasan masyarakat adalah pendapat masyarakat dalam memperoleh pelayanan dari aparatur penyelenggara pelayanan publik dengan membandingkan antara harapan dan kebutuhannya (Kepmen PAN Nomor : 25 Tahun 2004 tentang Pedoman Umum Penyusunan Indeks Kepuasan Masyarakat Unit Pelayanan Instansi Pemerintah).

Keberhasilan sebuah organisasi sangat dipengaruhi oleh kinerja para pegawainya. Kinerja merupakan prestasi kerja, yakni perbandingan antara hasil kerja yang secara nyata dengan standar kerja yang ditetapkan (Dessler,1992). Setiap organisasi berusaha untuk meningkatkan kinerja karyawannya demi tercapainya tujuan yang telah ditetapkan oleh organisasi. Berbagai cara dapat ditempuh oleh organisasi dalam meningkatkan kinerja pegawainya diantaranya dengan mewujudkan kepuasan kerja karyawan melalui budaya organisasi dan gaya kepemimpinan yang sesuai dengan harapan karyawan dan masyarakat.

Penilaian kinerja amat penting bagi suatu organisasi. Dengan penilaian kinerja tersebut suatu organisasi dapat melihat sejauh mana faktor manusia dapat menunjang tujuan suatu organisasi. Penilaian terhadap prestasi dapat memotivasi pegawai agar terdorong untuk bekerja lebih baik. Oleh karena itu diperlukan penilaian kinerja yang tepat dan konsisten.

Kualitas sebuah organisasi pemerintah dalam bidang pelayanan publik bersumber pada sumber daya manusia yang menjadi salah satu kunci keberhasilan dalam memajukan sebuah organisasi. Dimana SDM sangat dibutuhkan sebagai penentu yang sangat penting bagi keefektifan berjalannya kegiatan di dalam organisasi. Keberhasilan dan kinerja seseorang dalam suatu bidang pekerjaan banyak ditentukan oleh tingkat kompetensi, integeritas, profesionalisme dan etos kerja petugas. Selain itu sumber daya manusia yang ada dapat menciptakan dan mengembangkan iklim dan budaya kerja yang kondusif. Hal ini berkaitan dengan tujuan organisasi dalam rangka optimalisasi pengembangan SDM berbasis teknologi informasi. 
Sebuah organisasi dituntut untuk mampu meningkatkan kualitas SDM yang ada.

Berdasarkan hal-hal uraian singkat di atas, dengan latar belakang dan gagasan yang diungkapkan penulis merasa tertarik untuk meneliti dan menyusun tesis dengan judul : "Pengaruh Kualitas Pelayanan dan Kinerja Pegawai Terhadap Kepuasan Masyarakat (Keluarganya Warga Binaan Pemasyarakatan) Pada Lembaga Pemasyarakatan Kelas IIB Slawi”.

\section{METODE PENELITIAN}

Jenis penelitian yang digunakan dalam penelitian ini adalah jenis survey menggunakan pendekatan kuantitatif dan juga di lakukan wawancara secara mendalam (indepth interview). Lokasi penelitian ini tepatnya di Kota Slawi Kabupaten Tegal Provinsi Jawa tengah. Instansi yang dijadikan obyek penelitian oleh penulis adalah Lembaga Pemasyarakatan Kelas IIB Slawi.

Penelitian ini dirancang dengan tujuan untuk menganalisis hubungan antar variabel. Rancangan penelitian ini termasuk penelitian korelasional, yaitu penelitian yang dilakukan dengan maksud menganalisis hubungan antarvariabel. Variabel-variabel yang digunakan adalah kualitas layanan, kinerja pegawai dan kepuasan masyarakat. sebagaimana diungkapkan dalam hipotesis, masing-masing akan diuraikan dalam indikator yang sesuai dan selanjutnya diturunkan menjadi item pertanyaan dalam instrumen penelitian.

Teknik pengambilan sampel adalah dengan menggunakan non probability sampling, yaitu semua elemen dalam populasi tidak memiliki kesempatan yang sama untuk dipilih menjadi sampel (Ferdinand, 2006:231). Hal ini dilakukan karena mengingat keterbatasan waktu yang ada. Metode pengambilan sampelnya menggunakan conveniencelaccidental sampling, yaitu teknik penentuan sampel berdasarkan kebetulan, yaitu siapa yang secara kebetulan bertemu dengan peneliti, bila dipandang cocok dapat dijadikan sampel sebagai sumber data. Penentuan jumlah sampel dalam penelitian ini menggunakan rumus Slovin. Rumus tersebut dituliskan sebagai berikut (Umar, 2001) :

$$
n=\frac{N}{1+N(e)^{2}}
$$

Keterangan :

$\mathrm{n}=$ Jumlah sampel

$\mathrm{N}=$ Jumlah populasi

$\mathrm{E}=$ Tingkat kesalahan

Populasi (N) sebanyak 300 orang pengunjung Lembaga Pemasyarakatan Kelas IIB Slawi dengan asumsi taraf kesalahan (e) sebesar 5\%, maka jumlah sampel (n) adalah :

$$
n=\frac{300}{1+300(0.05)^{2}}=171,43 \approx 171 \text { orang }
$$

Maka jumlah sampel dalam penelitian ini adalah sebanyak 171 orang pengunjung keluarganya warga binaan pemasyarakatan pada Lembaga Pemasyarakatan Kelas IIB Slawi.

Penelitian ini, menggunakan Analisis Regresi Linear Berganda digunakan untuk mengetahui pengaruh variabel-variabel pelayanan dan kinerja pegawai terhadap kepuasan masyarakat. Analisis yang digunakan dalam penelitian ini adalah menggunakan uji hipotesis, uji prasyarat dan uji sample yaitu (1) uji prasyarat meliputi uji validitas dan uji reliabilitas, (2) uji hipotesis meliputi uji Fsimultan dan uji t parsial serta (3) uji sampel yang terdiri dari uji heteroskedastisitas, uji normalitas, dan uji multikolinearitas.

Dalam menganalisis permasalahan yang dikemukakan dalam penelitian ini, digunakan persamaan regresi ber- 
ganda, dengan menggunakan Statistical Package for Social Science (SPSS) 20.0.

Secara garis besar, kerangka berfikir Pengaruh Kualitas Pelayanan dan Kinerja Pegawai Terhadap Kepuasan Masyarakat (Keluarganya Warga Binaan Pemasyarakatan) Pada Lembaga Pemasyarakatan Kelas IIB Slawi.

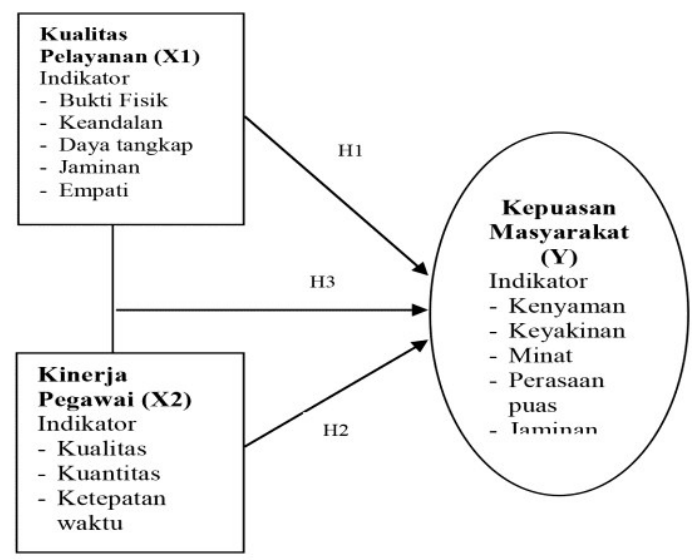

Gambar 1

Model Rencana Penelitian

\section{HASIL PENELITIAN DAN PEMBASAN}

\section{Persamaan Regresi Linier Berganda}

Berdasarkan hasil pengolahan data dengan menggunakan software SPSS 20.0, maka persamaan regresi linear berganda dari data penelitian diperoleh persamaan sebagai berikut :

$$
Y=4,211+0,216 X 1+0,469 X 2
$$

Tabel 1

Data Hasil Pengolahan Persaamaan Regresi Linear Berganda

\begin{tabular}{|c|l|c|c|c|}
\hline \multicolumn{2}{|c|}{ Model } & \multicolumn{2}{|c|}{$\begin{array}{c}\text { Unstandardized } \\
\text { Coefficients }\end{array}$} & \\
\cline { 2 - 5 } \multicolumn{2}{|c|}{} & B & $\begin{array}{c}\text { Std. } \\
\text { Error }\end{array}$ & Sig \\
\hline \multirow{3}{*}{1} & (Constant) & 4,211 & 2,320 & 0,071 \\
\cline { 2 - 5 } & $\begin{array}{l}\text { Kualitas } \\
\text { Layanan }\end{array}$ & 0,216 & 0,076 & 0,004 \\
\cline { 2 - 5 } & $\begin{array}{l}\text { Kinerja } \\
\text { Pegawai }\end{array}$ & 0,469 & 0,124 & 0,000 \\
\hline
\end{tabular}

a. Dependent Variabel: Kepuasan Masyarakat
Dari persamaan Regresi diatas dapat diinterpretasikan beberapa hal antara lain :

1) Nilai konstanta persamaan di atas sebesar 4.211. Angka tersebut menunjukkan tingkat variabel kepuasan masyarakat dengan asumsi variabel independen (kualitas layanan dan kinerja pegawai) diabaikan.

2) Variabel kualitas layanan memiliki nilai koefisien regresi sebesar 0,216. Nilai koefisien positif menunjukkan hubungan positif kualitas layanan terhadap tingkat kepuasan masyarakat (keluarganya warga binaan pemasyarakatan) di Lembaga Pemasyarakatan Kelas IIB Slawi. Hal ini berarti bahwa jika terjadi kenaikan kualitas layanan, maka nilai kepuasan (masyarakat keluarganya warga binaan pemasyarakatan) di Lembaga Pemasyakatan Kelas IIB Slawi akan mengalami peningkatan sebesar koefisien pengalinya dengan asumsi variabel independen yang lain (kinerja pegawai) dianggap konstan.

3) Variabel kinerja pegawai memiliki nilai koefisien regresi sebesar 0,469. Nilai koefisien positif menunjukkan hubungan positif kinerja pegawai terhadap tingkat kepuasan masyarakat (keluarganya warga binaan pemasyarakatan) di Lembaga Pemasyarakatan Kelas IIB Slawi. Hal ini berarti bahwa jika terjadi kenaikan kinerja pegawai, maka nilai kepuasan masyarakat (keluarganya warga binaan pemasyarakatan) di Lembaga Pemasyarakatan Kelas IIB Slawi akan mengalami peningkatan sebesar koefisien pengalinya dengan asumsi variabel independen yang 
lain (kualitas layanan) dianggap konstan.

\section{Analisis Koefisien Determinasi $\left(\mathbf{R}^{2}\right)$}

Uji koefisien determinasi untuk mengetahui seberapa erat pengaruh kualitas layanan dan kinerja pegawai terhadap kepuasan masyarakat. Hasil pengolahan data uji koefisien determinasi dengan SPSS dapat dilihat pada tabel dibawah ini.

Tabel 2.

Data Hasil Uji Determinasi

\begin{tabular}{|c|c|c|c|c|}
\hline Model & $\mathrm{R}$ & $\begin{array}{c}\mathrm{R} \\
\text { Square }\end{array}$ & $\begin{array}{c}\text { Ajusted } \\
\text { Square }\end{array}$ & $\begin{array}{c}\text { Std Error } \\
\text { the } \\
\text { Estimate }\end{array}$ \\
\hline 1 & $0,652^{\mathrm{a}}$ & 0,425 & 0,419 & 3,768 \\
\hline
\end{tabular}

a. Predictors : (Constant), Kualitas Layanan, Kinerja Pegawai

b. Dependent Variabel : Kepuasan masyarakat.

Berdasarkan hasil olah data menggunakan SPSS didapatkan nilai koefisien determinasi $\mathrm{R}^{2}$ sebesar 0,425 hal ini menunjukkan bahwa sebesar 42,5\% kepuasan masyarakat dipengaruhi oleh variasi kedua variabel independent yang digunakan, yaitu kualitas layanan dan kinerja pegawai di Lembaga Pemasyarakatan Kelas IIB Slawi, sedangkan sisanya dipengaruhi oleh faktor lain yang tidak dibahas dalam penelitian ini. Dengan demikian hubungan kedua variabel bisa dikatakan cukup kuat karena Rsquare bernilai hampir setengah dari faktor yang mempengaruhi kepuasan (masyarakat keluarganya warga binaan pemasyarakatan) di Lembaga Pemasyarakatan Kelas IIB Slawi.

\section{Uji Prasyarat a. Uji Validitas Instrumen}

Uji validitas digunakan untuk mengukur sah atau valid tidaknya suatu kuesioner. Syarat keputusan dari kuesioner itu valid tidaknya adalah dengan membandingkan hasil SPSS ditunjukkan dengan nilai korelasi (pearson correlation) disebut juga dengan $r_{\text {hitung dengan }} r_{\text {tabel }}$. Dalam penelitian ini $r_{\text {tabel }}$ menggunakan degree of freedom $=\mathrm{n}-2=171-2=169$ dan menggunakan taraf signifikasi 0,05 sehingga $r_{\text {tabel }}(169 ; 0,05)=0,1501$.

Syarat keputusan kuesioner tersebut valid jika $r_{\text {hitung lebih besar dengan }}$ $\mathrm{r}_{\text {tabel }}$ maka kuesioner tersebut dikatakan valid, sehingga dapat digunakan untuk pengumpul data.

Berikut ini hasil uji validitas pada masing-masing variabel Kualitas Pelayanan (X1), Kinerja Pegawai (X2), dan Kepuasan Masyarakat (Y) sebagai berikut :

Tabel 3.

Uji Validitas Terhadap Valiabel Kualitas Layanan

\begin{tabular}{|c|c|c|c|c|}
\hline No & Pertanyaan & rhitung & rtabel & Keterangan \\
\hline 1 & $\mathrm{X} 1.1$ & 0,754 & 0,1501 & VALID \\
\hline 2 & $\mathrm{X} 1.2$ & 0,715 & 0,1501 & VALID \\
\hline 3 & $\mathrm{X} 1.3$ & 0,772 & 0,1501 & VALID \\
\hline 4 & $\mathrm{X} 1.4$ & 0,821 & 0,1501 & VALID \\
\hline 5 & $\mathrm{X} 1.5$ & 0,806 & 0,1501 & VALID \\
\hline 6 & $\mathrm{X} 1.6$ & 0,812 & 0,1501 & VALID \\
\hline 7 & $\mathrm{X} 1.7$ & 0,812 & 0,1501 & VALID \\
\hline 8 & $\mathrm{X} 1.8$ & 0,809 & 0,1501 & VALID \\
\hline 9 & $\mathrm{X} 1.9$ & 0,799 & 0,1501 & VALID \\
\hline 10 & $\mathrm{X} 1.10$ & 0,84 & 0,1501 & VALID \\
\hline 11 & $\mathrm{X} 1.11$ & 0,815 & 0,1501 & VALID \\
\hline 12 & $\mathrm{X} 1.12$ & 0,817 & 0,1501 & VALID \\
\hline 13 & $\mathrm{X} 1.13$ & 0,803 & 0,1501 & VALID \\
\hline 14 & $\mathrm{X} 1.14$ & 0,76 & 0,1501 & VALID \\
\hline 15 & $\mathrm{X} 1.15$ & 0,762 & 0,1501 & VALID \\
\hline
\end{tabular}


Tabel 4.

Uji Validitas Terhadap Valiabel Kinerja Pegawai

\begin{tabular}{|c|c|c|c|c|}
\hline No & Pertanyaan & rhitung & rtabel & Keterangan \\
\hline 1 & $\mathrm{X} 2.1$ & 0,813 & 0,1501 & VALID \\
\hline 2 & $\mathrm{X} 2.2$ & 0,745 & 0,1501 & VALID \\
\hline 3 & $\mathrm{X} 2.3$ & 0,826 & 0,1501 & VALID \\
\hline 4 & $\mathrm{X} 2.4$ & 0,801 & 0,1501 & VALID \\
\hline 5 & $\mathrm{X} 2.5$ & 0,819 & 0,1501 & VALID \\
\hline 6 & $\mathrm{X} 2.6$ & 0,822 & 0,1501 & VALID \\
\hline 7 & $\mathrm{X} 2.7$ & 0,802 & 0,1501 & VALID \\
\hline 8 & $\mathrm{X} 2.8$ & 0,776 & 0,1501 & VALID \\
\hline 9 & $\mathrm{X} 2.9$ & 0,793 & 0,1501 & VALID \\
\hline 10 & $\mathrm{X} 2.10$ & 0,806 & 0,1501 & VALID \\
\hline
\end{tabular}

Tabel 5.

Uji Validitas Terhadap Valiabel Kepuasan Masyarakat

\begin{tabular}{|c|c|c|c|c|}
\hline No & Pertanyaan & rhitung & rtabel & Keterangan \\
\hline 1 & Y1 & 0,645 & 0,1501 & VALID \\
\hline 2 & Y2 & 0,636 & 0,1501 & VALID \\
\hline 3 & Y3 & 0,644 & 0,1501 & VALID \\
\hline 4 & Y4 & 0,584 & 0,1501 & VALID \\
\hline 5 & Y5 & 0,605 & 0,1501 & VALID \\
\hline 6 & Y6 & 0,627 & 0,1501 & VALID \\
\hline 7 & Y7 & 0,641 & 0,1501 & VALID \\
\hline 8 & Y8 & 0,701 & 0,1501 & VALID \\
\hline 9 & Y9 & 0,675 & 0,1501 & VALID \\
\hline
\end{tabular}

Berdasarkan hasil uji validitas menunjukkan bahwa nilai korelasi (rhitung) tiap item pertanyaan dengan skor nilai yang diperoleh lebih besar dari dari $r_{\text {tabel }}$ yang sebesar 0,1501 . Sehingga dapat disimpulkan bahwa keseluruhan item pertanyaan pada variabel Kualitas Pelayanan, Kinerja Pegawai dan Kepuasan Masyarakat yang digunakan adalah valid dan dapat digunakan dalam analis data selanjutnya.

\section{b. Uji Riliabilitas Instrumen}

Uji reliabilitas dimaksudkan untuk mengukur suatu kuesioner yang merupakan indikator dari variabel. Reabilitas diukur dengan uji statistik cronbach's alpha (á). Suatu variabel dikatakan reliabel/handal jika memberikan nilai cronbach' alpha $>r_{\text {tabel }}$. Nilai $r_{\text {tabel }}=r_{\text {tabel }}(169: 0,05)$ pada penelitian ini adalah $=0,1501$

Berikut ini hasil uji reliabilitas pada masing-masing variabel Kualitas
Pelayanan (X1), Kinerja Pegawai (X2), dan Kepuasan Masyarakat (Y) sebagai berikut :

Tabel 6.

Hasil Uji Reliabilitas Terhadap Variabel Kualitas Layanan

\begin{tabular}{|r|r|}
\hline Cronbach's Alpha & \multicolumn{2}{|c|}{ N of Items } \\
\hline 0,958 & 15 \\
\hline
\end{tabular}

Tabel 7

Hasil Uji Reliabilitas Terhadap Variabel Kinerja Pegawai

\begin{tabular}{|r|r|}
\hline Cronbach's Alpha & N of Items \\
\hline 0,937 & 10 \\
\hline
\end{tabular}

Tabel 8.

Hasil Uji Reliabilitas Terhadap

Variabel Kepuasan Masyarakat

\begin{tabular}{|c|c|}
\hline Cronbach's Alpha & $\mathrm{N}$ of Items \\
\hline 0,575 & 9 \\
\hline
\end{tabular}

Berdasarkan hasil uji reliabilitas yang dilakukan terhadap semua item pertanyaan dalam penelitian ini menunjukkan bahwa semua item pertanyaan dapat dikatakan reliabel/terpercaya, dengan nilai Cronbach's Alpha sebesar 0,958, 0,937 dan 0,575 lebih besar dibanding dengan rtabel sebesar 0,1501, dengan demikian semua item pertanyaan dalam setiap variabel dapat dipercaya sebagai alat pengumpul data.

\section{Uji Instrumen ( Sample )}

\section{1) Uji Normalitas}

Uji normalitas bertujuan untuk menguji apakah dalam model regresi variabel pengganggu atau residual memiliki distribusi normal. Untuk mengetahui dalam suatu data berdistribusi normal atau tidak, maka digunakan uji Kolmogorov-Smirnov. Bila nilai signifikansi $>\alpha(0,05)$, maka data berdistri- 
busi normal. Hasil uji normalitas variabel kualitas layanan, kinerja pegawai terhadap kepuasan masyarakat dapat dilihat pada tabel dibawah ini :

Tabel 9.

Hasil Uji Normalitas Kolmogorov-Smirnov Pada Variabel Kualitas

\begin{tabular}{|l|l|r|}
\hline \multicolumn{2}{|l|}{} & $\begin{array}{c}\text { Unstandardized } \\
\text { Residual }\end{array}$ \\
\hline N & 171 \\
\hline \multirow{3}{*}{ Normal Parameters } & Mean & $0 \mathrm{E}-7$ \\
\cline { 2 - 3 } & $\begin{array}{l}\text { Std. } \\
\text { Deviation }\end{array}$ & 3,74565017 \\
\hline \multirow{3}{*}{$\begin{array}{l}\text { Most Extreme } \\
\text { Differences }\end{array}$} & Absolute & 0,186 \\
\cline { 2 - 3 } & Positive & 0,186 \\
\cline { 2 - 3 } & Negative & $-0,162$ \\
\hline Kolmogorov-Smirnov Z & 1,032 \\
\hline Asymp. Sig. (2-tailed) & & 0,071 \\
\hline
\end{tabular}

a. Test distribution is Normal.

b. Calculated from data.

\section{Layanan, Kinerja Pegawai Terhadap Kepuasan Masyarakat}

Berdasarkan hasil tabel diatas dapat dilihat bahwa sebaran data penelitan ini normal, hal ini ditunjukkan dengan nilai signifikasi $>\alpha(0,05)$ yaitu $0,071>0,05$.

\section{Uji Heteroskedasitas}

Hasil uji heroskedastisitas dengan korelasi rank spearman antara variabel bebas dengan nilai residual. Jika korelasi rank spearman menghasilkan nilai signifikansi $>0,05 \quad(\alpha=5 \%)$, maka disimpulkan dalam model regresi tidak ada heteroskedastisitas.

Hasil uji heroskedastisitas dengan korelasi rank spearman antara variabel bebas dengan nilai residual. Jika korelasi rank spearman menghasilkan nilai signifikansi $>0,05 \quad(\alpha=5 \%)$ maka disimpulkan dalam model regresi tidak ada heteroskedastisitas.

Tabel 10.

Data Hasil Uji Heteroskedasitas

\begin{tabular}{|c|c|c|c|c|c|}
\hline \multirow[t]{2}{*}{ Model } & \multicolumn{2}{|c|}{$\frac{\text { Unstandardzied }}{\underline{\text { Coefficients }}}$} & $\frac{\underline{\text { Standardized }}}{\underline{\text { Coefficients }}}$ & \multirow{2}{*}{$\underline{\mathrm{T}}$} & \multirow{2}{*}{$\underline{\text { Sig }}$} \\
\hline & $\underline{B}$ & $\underline{\text { Std Eror }}$ & Beta & & \\
\hline (Constan) & $\underline{3.312}$ & $\underline{1.981}$ & & 1.672 & $\underline{0.096}$ \\
\hline$\underline{\text { Kualitas }}$ & -0.072 & $\underline{0.065}$ & $\underline{-0.150}$ & -1.108 & $\underline{0.270}$ \\
\hline$\frac{\text { Kinerja }}{\text { Pegawai }}$ & $\underline{0.065}$ & $\underline{0.106}$ & $\underline{0.083}$ & $\underline{0.609}$ & $\underline{0.543}$ \\
\hline
\end{tabular}

Berdasarkan tabel diatas menunjukkan nilai signifikansi korelasi rank spearman dari variabel bebas semuanya $>0,05$, yaitu 0270 dan $0,543>0,05$. Dari penjelasan di atas maka dapat disimpulkan bahwa tidak terjadi heteroskedastisitas dalam model regresi.

\section{Uji Multikolinearitas}

Untuk uji multikolinieritas, pendeteksian ada tidaknya multikolinieritas dilakukan dengan melihat nilai tolerance dan VIF. Jika nilai tolerance $>0,1$ dan VIF $<10$, maka dalam model regresi tidak ada multikolinieritas.

Tabel 11.

Data Hasil Uji Multikolinearitas

\begin{tabular}{|c|c|c|c|c|c|}
\hline Model & $\begin{array}{l}\text { Sum of } \\
\text { Squares }\end{array}$ & $\mathrm{df}$ & $\begin{array}{l}\text { Mean } \\
\text { Square }\end{array}$ & $\bar{F}$ & Sig. \\
\hline Regression & 1765,561 & 2 & 882,781 & 62,181 & $0,000^{b}$ \\
\hline 1 Residual & 2385,082 & 168 & 14,197 & & \\
\hline Total & 4150,643 & 170 & & & \\
\hline
\end{tabular}

Berdasarkan tabel diatas diketahui bahwa nilai tolerance variabel bebas semuanya $>0,1$, demikian pula nilai $\mathrm{VIF}$ semuanya $<10$, sehingga dapat 
disimpulkan model regresi bebas dari multikolinieritas.

\section{Uji Hipotesis \\ 1) $\mathbf{U j i} F$}

Uji $F$ digunakan untuk menguji pengaruh simultan (bersama - sama) dua atau lebih variabel bebas/independent terhadap variabel terikat/dependent. Jika uji $\mathrm{F}$ menghasilkan $\mathrm{F}_{\text {hitung }}>\mathrm{F}_{\text {tabel }}$ dan nilai signifikansi $<0,05(\alpha=5 \%)$, maka H0 ditolak dan $\mathrm{H} 1$ diterima, sehingga dapat disimpulkan variabel bebas secara simultan berpengaruh signifikan terhadap variabel terikat. Hipotesis yang diasumsikan pada penelitian ini adalah :

H0 : Diduga kualitas layanan (X1) dan kinerja pegawai (X2) secara simultan tidak berpengaruh positif dan signifikan terhadap kepuasan masyarakat (keluarganya warga binaan pemasyarakatan) di Lembaga Pemasyarakatan Kelas IIB Slawi

H3 : Diduga kualitas layanan (X1) dan kinerja pegawai (X2) secara simultan berpengaruh positif dan signifikan terhadap kepuasan masyarakat (keluarganya warga binaan pemasyarakatan) di Lembaga Pemasyarakatan Kelas IIB Slawi (Y)

Tabel 12.

Uji F Simultan Pengaruh Kualitas Layanan dan Kinerja Pegawai Terhadap Kepuasan Masyarakat (Sumber: data,diolah,2016)

\begin{tabular}{|c|c|c|c|}
\hline \multirow{2}{*}{\multicolumn{2}{|c|}{ Model }} & \multicolumn{2}{|c|}{$\begin{array}{c}\text { Collinearity } \\
\text { Statistics }\end{array}$} \\
\hline & & Tolerance & VIF \\
\hline \multirow{3}{*}{1} & (Constant) & & \\
\hline & $\begin{array}{l}\text { Kualitas } \\
\text { Layanan }\end{array}$ & 0,322 & 3,108 \\
\hline & $\begin{array}{l}\text { Kinerja } \\
\text { Pegawai }\end{array}$ & 0,322 & 3,108 \\
\hline
\end{tabular}

Berdasarkan tabel diatas dari tabel diatas dapat diperoleh diketahui $\mathrm{F}$ hitung $=62,181>\mathrm{F}_{\text {tabel }} 3,05(\mathrm{dfl}=2$, $\mathrm{df} 2=168, \alpha=0,05)$, dengan nilai signifikansi $=0,000<0,05$, maka H0 ditolak dan Ha diterima. Berdasarkan hasil ini dapat disimpulkan bahwa kualitas layanan dan kinerja pegawai berpengaruh positif dan signifikan terhadap kepuasan (masyarakat keluarganya warga binaan pemasyarakatan) di Lembaga Pemasyarakatan Kelas IIB Slawi. Hal ini berarti hipotesis ketiga penelitian dapat diterima.

\section{2) Uji t}

Uji parsial dalam penelitian ini adalah menguji masing-masing variabel independent secara sendiri-sendiri terhadap variabel dependent. Syarat keberterimaan uji $\mathrm{t}$ adalah $\mathrm{t}_{\text {hitung }}>\mathrm{t}_{\text {tabel }}$, dengan nilai signifikansi $<0,05$.

Tabel 13.

Uji t Parsial Pengaruh Kualitas Layanan dan Kinerja Pegawai Terhadap Kepuasan Masyarakat

\begin{tabular}{|c|c|c|c|c|c|c|}
\hline \multirow{2}{*}{\multicolumn{2}{|c|}{ Model }} & \multicolumn{2}{|c|}{$\begin{array}{c}\text { Unstandardized } \\
\text { Coefficients }\end{array}$} & \multirow{2}{*}{$\begin{array}{c}\begin{array}{c}\text { Standardized } \\
\text { Coefficients }\end{array} \\
\text { Beta }\end{array}$} & \multirow[t]{2}{*}{$\mathrm{t}$} & \multirow[t]{2}{*}{ Sig. } \\
\hline & & B & $\begin{array}{l}\text { Std. } \\
\text { Error }\end{array}$ & & & \\
\hline \multirow{3}{*}{1} & (Constant) & 4,211 & 2,320 & & 1,815 & 0,071 \\
\hline & $\begin{array}{l}\text { Kualitas } \\
\text { Layanan }\end{array}$ & 0,216 & 0,076 & 0,293 & 2,845 & 0,004 \\
\hline & $\begin{array}{l}\text { Kinerja } \\
\text { Pegawai }\end{array}$ & 0,469 & 0,124 & 0,389 & 3,774 & 0,000 \\
\hline
\end{tabular}

\section{1). Hipotesis Pertama}

H0 : Diduga kualitas layanan secara parsial tidak berpengaruh positif dan signifikan terhadap kepuasan masyarakat (keluarganya warga binaan pemasyarakatan) di Lembaga Pemasyarakatan Kelas IIB Slawi (Y)

H1 : Diduga kualitas layanan (X1) secara parsial berpengaruh positif dan signifikan terhadap kepuasan masyarakat (keluarganya warga binaan pema- 
syarakatan) di Lembaga Pemasyarakatan Kelas IIB Slawi (Y)

Berdasarkan tabel diatas dari tabel diatas dapat diperoleh penjelasan sebagai berikut : Pengujian pengaruh kualitas layanan (X1) terhadap kepuasan masyarakat (keluarganya warga binaa pemasyarakatan) (Y) menghasilkan $t_{\text {hitung }}$ $=2,845>t_{\text {tabel }}, t_{\text {tabel }} 1,653 \quad(\mathrm{df}=169$, $\alpha=0,05$ ), dengan nilai signifikansi $=$ $0,004<0,05$, maka H0 ditolak dan H1 diterima. Berdasarkan hasil ini dapat disimpulkan bahwa kualitas layanan berpengaruh positif dan signifikan terhadap kepuasan masyarakat (keluarganya warga binaan pemasyarakatan) di Lembaga Pemasyarakatan Kelas IIB Slawi. Kuantitas dan kualitas dari kualitas layanan yang semakin baik, akan meningkatkan secara positif dan signifikan terhadap kepuasan masyarakat (keluarganya warga binaan pemasyarakatan) di Lembaga Pemasyarakatan Kelas IIB Slawi sehingga masyarakata akan memberikan apresiasi positif terhadap kinerja pelayanan publik yang di lakukan oleh pegawai Lembaga Pemasyarakatan Kelas IIB Slawi.

\section{2). Hipotesis Kedua}

$\mathrm{H} 0$ : Diduga kinerja pegawai (X2) secara parsial tidak berpengaruh positif dan signifikan terhadap kepuasan masyarakat (keluarganya warga binaan pemasyarakatan) di Lembaga pemasyarakatan Kelas IIB Slawi. (Y)

$\mathrm{H} 2$ : Diduga kinerja pegawai (X2) secara parsial berpengaruh positif dan signifikan terhadap kepuasan masyarakat (keluarganya warga binaan pemasyarakatan) di Lembaga Pemasyarakatan Kelas II Slawi (Y)
Berdasarkan tabel diatas dari dapat diperoleh penjelasan sebagai berikut : Pengujian kinerja pegawai (X2) terhadap kepuasan masyarakat (keluarganya warga binaan pemasyarakatan) (Y) di Lembaga Pemasyarakatan Kelas IIB Slawi menghasilkan $t_{\text {hitung }}=3,774>$ $t_{\text {tabel, }} t_{\text {tabel }} 1,653(d f=169, \alpha=0,05)$, dengan nilai signifikansi $=0,000<0,05$, maka $\mathrm{H} 0$ ditolak dan $\mathrm{H} 2$ diterima. Berdasarkan hasil ini dapat disimpulkan bahwa kinerja pegawai berpengaruh positif dan signifikan terhadap kepuasan masyarakat (keluarganya warga binaan pemasyarakatan) di Lembaga Pemasyarakatan Kelas IIB Slawi. Kuantitas dan kualitas dari kinerja pegawai yang semakin baik, akan meningkatkan secara positif dan signifikan terhadap kepuasan masyarakat (keluarganya warga binaan pemasyarakatan) di Lembaga Pemasyarakatan Kelas IIB Slawi sehingga masyarakata akan memberikan apresiasi positif terhadap kinerja pelayanan publik yang di lakukan oleh pegawai Lembaga Pemasyarakatan Kelas IIB Slawi.

\section{IV.SIMPULAN DAN SARAN a. Simpulan}

Berdasarkan pembahasan pada bab 4, maka dapat diambil beberapa kesimpulan sebagai berikut :

1. Kualitas Layanan (X1) dan kinerja Pegawai (X2) secara bersama sama berpengaruh positif dan signifikan terhadap kepuasan masyarakat (keluarganya warga binaan pemasyarakatan) (Y) di Lembaga Pemasyarakatan Kelas IIB Slawi.

2. Kualitas Layanan (X1) secara parsial berpengaruh positif dan signifikan terhadap kepuasan masyarakat (keluarganya warga binaan pemasyarakatan) (Y) di Lembaga Pemasyarakatan Kelas IIB Slawi. 
3. Kinerja Pegawai (X2) secara parsial berpengaruh positif dan signifikan terhadap kepuasan masyarakan (keluarganya warga binaan pemasyarakatan) (Y) di Lembaga Pemasyarakatan Kelas IIB Slawi.

\section{b. Saran}

Berdasarkan kesimpulan hasil penelitian, dapat disarankan hal-hal sebagai berikut kepada pimpinan dan segenap pegawai Lembaga Pemasyarakatan untuk menjadi perhatian dan masukan :

1. Mengingat bahwa Kualitas Pelayanan Publik berpengaruh terhadap Kepuasan Masyarakat, maka Kepala Lembaga Pemasyarakatan sebagai pimpinan harus meningkatkan kualitas pelayanan yang diberikan oleh para pegawai yang menjadi bawahannya harus tuntas dan bertanggung jawab, artinya ketika memberikan pelayanan kepada masyarakat harus seoptimal mungkin dalam rangka meningkatkan kepuasan masyarakat keluarganya warga binaan pemasyarakatan.
2. Kepala Lembaga Pemasyarakatan perlu memperhatikan implementasi dari masing-masing faktor Kualitas Pelayanan Publik berupa Struktur Organisasi, Kemampuan Aparat dan Sistem Pelayanan transparan demi mengoptimalkan Kepuasan Masyarakat keluarganya warga binaan pemasyarakatan.

3. Dalam rangka meningkatkan kontribusi terhadap Kepuasan Masyarakat (keluarganya warga binaan pemasyarakatan) di Lembaga Pemasyarakatan Kelas IIB Slawi, maka pimpinan dan segenap aparat perlu memperluas dan meningkatkan upaya-upaya perbaikan dan pengembangan Kualitas Pelayanan Publik. Antara lain melalui peningkatan kualitas SDM dalam bentuk bimbingan teknis, diklat (struktural maupun fungsional), tugas belajar atau ijin belajar pada perguruan tinggi terdekat, melalui upaya mandiri berupa kursus komputer atau keterampilan lainnya yang mendukung dalam pemenuhan pelayanan publik kepada masyarakat.

\section{DAFTAR PUSTAKA}

A.A. Anwar Prabu Mangkunegara, 2005, Evaluasi kinerja SDM, Bandung: Penerbit PT. Refika Aditama.

Agus Dwiyanto, 2005, Mewujudkan Good Governance Melalui Pelayanan Publik, Yogyakarta: Gadjah Mada Univ. Press.

Alamsyah, 2011, "Karakteristik Universal Pelayanan Publik : Sebuah Tinjauan Teoritik”. "Jurnal Borneo Administrator". Vol. 7 No. 3 Tahun 2011. P 353-372.

Arikunto, Suharsimi, 2006, Prosedur Penelitian Suatu Pendekatan Praktek, Jakarta: Rineka Cipta.

Atmaja, Arief Kusuma, 2002, Kualitas Pelayanan Publik di Unit Pelayanan Terpadu (UPT) kabupaten Jember, Tesis Mahasiswa UGM. 
Atmawati, Rustika, dan Wahyuddin, 2007, "Analisis Pengaruh Kualitas Pelayanan Terhadap Kepuasan Konsumen Pada Matahari Departement Store Di Solo Grand Mall", "Jurnal Ekonomi dan Bisnis". Surakarta: Hal. 1-12. Universitas Muhammadiyah Surakarta.

Atmosoeprapto, Krisdarto, 2001, Produktivitas Analis Budaya Perusahaan, Jakarta: PT. Elex Media Komputindo.

Augusty Ferdinand. 2006. Metode Penelitian Manajemen : Pedoman Penelitian untuk Penulisan Skripsi, Tesis, dan Disertasi Ilmu Manajemen. Semarang: Badan Penerbit Universitas Diponegoro.

Azwar, Saifuddin, 2003, Reliabilitas dan Validitas, Yogyakarta: Pustaka Pelajar

Barata, Atep Adya, 2003, Dasar - Dasar Pelayanan Prima, Jakarta: PT. Elex Media.

Basuki, Yohanes, 2012, Budaya Pelayanan Publik, Jakarta: PT.Hartomo Media Pustaka.

Batinggi, Ahmad, 1999, Manajerial Pelayanan Umum, Jakarta: Universitas Terbuka.

Byars, Llloyd L dan Rue, Leslie W, 2006, Human Resource Management, 8 edition. MCGraw-Hill, Irwin.

Bernadine, 2005, “Analisis Pengaruh Kualitas Layanan terhadap Kepuasan Pelanggan Studi Kasus pada Rumah Makan Pondok Laras di Kelapa Dua, Depok”, "Jurnal Ekonomi Perusahaan", Vol. 12, No. 3 September 2005, h. 318-336.

Carmia Diahloka dan Achmad Bardjan Shaleh, melakukan penelitian "membangun kualitas pelayanan publik melalui peningkatan etos kerja pegawai Dinas Pertanian, Perikanan, dan Peternakan Kabupaten Sanggau”, "Jurnal Reformasi, Volume 3, Nomor 1", Januari - Juni 2013.

Casio, Waynw F, 1992, Managing Human Resaurces: Produktivity, Quality of Work Life, Profit, Singapure: McGraw-Hill Internasional Editor.

Dagger, Tracey S \& Jilian C. Sweeney 2007, "Service Quality Attribute Weights : Haw Do Novice and Longer-Term Customer Consgtrucr Service Quality Perseption", "Jurnal of Service Research, Vol.10.No.1", Agustus 2007 22-42 Sage Publications.

Denhardt, Janet V, Dan Denhardt, Robert B, 2003, The Publik Service: Serving, not Steering, New York: M.E. Sharpe, Inc.

Dessler, Garry, 2006, Manajemen Sumber Daya Manusia, Jakarta: Indeks.

Dharma, Surya, 2005, Manajemen Kinerja Falsafah, Teori dan Penerapannya, Yogyakarta: Pustaka Pelajar.

Dutka (1994:41). Atribut - Atribut Dari Konsumen Secara Universal, Erlanggan, Glora Aksara Pertama.

Engel, James F, et al. (1990) Customer Behavior, "Diterjemahkan" oleh F X Budiyanto, Perilaku Konsumen, Jilid II. Jakarta: Binarupa Aksara.

Fahmi, Irham, 2012, Manajemen Kinerja Teori dan Aplikasi, Bandung: Alfabeta. 
Fahmi Rezha, Siti Rochmah, Siswidiyanto, "Analis Pengaruh Kualitas Pelayanan Publik Terhadap Kepuasan Masyarakat", (Studi tentang Pelayanan Perekaman Kartu Tanda Penduduk Elektronik (e-KTP) di Kota Depok), "Jurnal Administrasi Publik (JAP)", Vol 1, No.5, Hal. 981-990| 98.

Ferdinand, Agusty, 2002, Structural Equqtion Modeling Dalam Penelitian

Manajemen, edisi 3, Semarang: BP UNDIP.

Ferdinand, A. 2006, Struktural Equating Modeling Dalam Penelitian Manajemen

(Aplikasi Model-Model Rumit dalam Penelitian untuk Tesis Magister dan Disertasi Doktor), Edisi 4, Semarang: BPUNDIP.

Furtwengler, Dale, 2002, Penuntun Sepuluh Menit Penilaian Kinerja : Menguasahi Keahlian Yang Ada Dalam Perlakuan Sepuluh Menit, Jogyakarta.

Gaspersz, Vincent, 1997, Manajemen Kualitas : Penerapan Konsep Vincent dalam Manajemen Bisnis Total, Jakarta: Gramedia Pustaka Utama.

Gaspersz, Vincent, 1997, Total Quality Management, Jakarta: PT. Gramedia Pustaka.

Gasperz, Vincent, 1997, Manajemen Kualitas Dalam Industri Jasa, Jakarta: PT. Gramedia Pustaka.

Gerson, Richard F, 2002, Mengukur Kepuasan Pelanggan, Jakarta: PPM.

Ghozali, Imam, 2012, Aplikasi Analisis Multivariate dengan Program SPSS, Semarang: BP Undip.

Groonroos, Christian, 1990, Good Service is Good Business, Sydney Australia: Prentice-Hall.

Gibson, James L. Rt al, 1996, Organisasi : Prilaku, Struktur, Proses, Jilit 1, "Terjemahan" Djarkosih, Jakarta: Penerbit ErLangga.

Hanke, E. Dan Reitsch, G. 1995, Business Forcasting, Sixth Edition, New Jersey: Printice-Hill.

Hasan, 2006, "Pengaruh Kualitas Jasa Bank Syariah Terhadap Kepuasan Nasabah pada Bank Muamalat Indonesia Cabang Semarang”, "Jurnal Ekonomi dan Bisnis", Vol. 1, No. 1 April 2006,h. 1 - 14.

Hersey, Paul, Kennteh H.Blanchard, 1993, Management of Organizational Behavior: Utilizing Human Resaurces, New Jersey: Printice-Hill Inc.

Ihsanuddin, 2014, "Kualitas Pelayanan Publik Pada Badan Perizinan Penanaman Modal Dan Promosi Daerah (BP2MPD) Kabupaten Indragiri Hilir", "Jurnal Administrasi Publik dan Birokrasi Vol. 1 No. 2, 2014”, artikel 9.

Islam, Nazrul. 2012, "Quality Of Civil Administration AndEconomic Growth" A Threshold Analysis. "The Journal of Deeloping Areas", Volume 46 No. 2 Fall 2012. P: 315-352.

Jonathan, Robin, 2005, "Pengaruh Kualitas Pelayanan terhadap Kepuasan Pelangganpada Sektor Publik di Kabupaten dan Kota di Propinsi Kalimantan Timur", "Jurnal Keuangan dan Perbankan", Th. IX. No. 2, Mei, Samarinda: Universitas 17 Agustus1945. 
Keban, Yeremias T, 2004, Enam Dimensi Strategis Administrasi Publik Konsep, Teoridan Isu, Yogyakarta: Gava Media.

Kurniawan, Agung, 2005, Transformasi Pelayanan Publik, Yogyakarta: Pembaruan.

Kotler, philip dkk, 2000, Manejemen Pemasan Jasa di Indonesia Analis Perencanaan, Implementasi dan Pengendalian (edisi pertama) Jakarta: Salemba Empat.

Lewis, R.C. and B.H. Booms 1983, “ The Marketing Aspects of Service Quality “ in Berry, L.L, G. Shostack, and G. Upah (eds), Emerging Perspectives in service marketing. Chicago: American Marketing Association, pp.99-107.

Lukman, Sampara, 1999, Manajemen Kualitas Pelayanan, Jakarta: STIA LAN.

Lupiyoadi, Rambat, 2001, Manajemen Pemasaran Jasa Teori dan Praktek, Edisi Pertama, Jakarta: Penerbit Salamba Emapat.

Lovelock, Christopher, Product Plus:Haw Product + Service $=$ Competitive Advantage, Mc Graw Hill iIntrnasional Editions.

Made Bagus Rangga Bhuwana dan Ida Bagus Sudiksa (2012) dalam penelitiannya pengaruh kualitas layanan layanan dan kepuasan pelanggan terhadap niat pemakaian ulang jasa service pada bengkel toyota auto 2000 Denpasar.

Mahmudi, 2005, Manajemen Kinerja Sektor Publik, Akademi Manajemen Perusahaan, Yoyakarta: YPKN.

Mahmudi, 2007, Manajemen Kinerja Sektor Publik, Yogyakarta: UPP STIM YKPN.

Mangkuegara, Anwar Prabu, DR, Msi, 2009, Evaluasi Kinerja SDM, Edisi Kedua, Bandung: Refika Aditama.

Moenir, AS 1999, Manajemen Umum Pelayanan di Indonesia, Jakarta: Bumi Aksara.

Morgan, Colin. \& Stephen Murgatroyd, 1994, Total Quality Management in the Public Sector, An Interactive Perspective, Buckingham: Open University Press.

Osborne, David, Peter Plastrik, 1999, Memangkas Birokrasi : Lima Strategi Menuju pemerintahan Wirausaha, terjemahan Abdul Rosyid, Ramelan, Jakarta: Pustaka Publik, Jakarta: Rinika Cipta.

Parasuraman A, Valarie A Zeithaml \& Leonard L. Berry, 1994, "Reassesment of Expectation As A Comparison Standart In Measuring Servive Quality: Implications For Futher Research", "Journal Of Marketing", Vol 58, pp 111-124.

Parasuraman A, Valarie A Zeithaml \& Leonard L. Berry, 1985, “A Conceptual Model of Service and Its Implication for Future Research", "Journal Of Marketing", Vol 49, Fall, pp 41-50.

Poerwadarminta, WJS 1994, Kamus Umum Bahasa Inggris-Indonesia dan IndonesiaInggris, Bandung: Hasta.

Prawirosentono, Suryadi, 1999, Manajemen Sumber Daya Manusia:Kebijakan Kinerja Karyawan, Kiat Menuju Organisasi Kompetitif dalam Perdaganagan Bebas Dunia, Yogyakatra: BPEE.

Rangkuti, Frendy, 2002, Measuring Costumer Statisfaction (edisi ketiga) Jakarta: Gramedia Pusaka Utama. 
Rasyid, Riyas M, 1997, Kajian Awal Birokrasi Pemerintahan dan Politik, Jakarta: Yasrif Watampone.

Rasyid, Riyas M, 2004, Manajemen PembangunanOtonomi Daerah, Bahan Semiloka Nasional, Jakarta: Ditjend PUOD.

Ratminto \& Atik SW, 2005, Manajemen Pelayanan : Pengembangan Model Konseptual, Penerapan Citizen's Charter \& SPM, Yogyakarta: Pustaka Pelajar.

Rayi Endah, 2008, “Analisis Kualitas Layanan, Kualitas Produk, dan Harga Terhadap Kepuasan Pelanggan”, Skripsi, Universitas Diponegoro.

Rivai, Veithzal Ahmad Fawzi Mohd. Basri, 2005, Performance Appraisa, Jakarta: Rajawali Press.

Robbins, Stephens P, 1996, Perilaku Organisasi, Edisi Bahasa Indonesia, Jakarata: Jilid I dan II, PT. Prenhallindo.

Robbins, Stephen P, “Diterjemahkan oleh Tim IndeX”, 2007, Perilaku Organisasi. Jilid II, Edisi 10, Jakarta: Gramedia.

S. Azwar, 1997, Metode Penelitian. Yogyakarta: Pustaka Pelajar.

Sedarmayanti, 2007, Manajemen Sumber Daya Manusia (reformasi birokrasidan manajemen pegawai negeri sipil), Bandung: PT.Refika Aditama.

Shermerhorn, Jhon R, Hunt James G, Osborn Richard N, 1991, Managing Organizational behavior, New York: John Willy \& Sons.

Siagian, Sondang P. 2001, Administrasi Pembangunan: Konsep, Dimensi dan Strateginya, Jakarta: Bumi Aksar.

Siddiqui, Shamim Ahmad, 2012, "Development and Growth through Economic Diversification: Are there Solutions for Continued Challenges Faced by Brunei Darussalam", "Journal of Economics and Behavioral Studies", Vol. 4, No. 7, pp. 397-413, July 2012. P: 397-405.

Sianipar, J.P.G. 1995, Manajemen Pelayanan Publik, Jakarta: LAN.

Sinambela, Linjan Poltak, 2016, Manajemen Sumber Daya Manusia (membengun tim kerja yang solid untuk meningkatkan kinerja), Jakarta: PT. Bumi Aksara.

Sinambela, Linjan Poltak, dkk. 2006, Reformasi Pelayanan Publik, Jakarta: PT. Bumi Aksara.

Sinambela, Linjan Poltak, 2012, Kinerja Pegawai:Teori, Pengukuran dan Implikasinya, Yogyakarta: PT. Graha Ilmu.

Soetarno (1994). Sikap, pengertian, definisi dan faktor yang mempengaruhi, From http://www.duniapsikologi.com/sikap-pengertian-definisi-dan faktor yang mempengaruhi/,4 juni 2013.

Sudjana. 2000. Metode Statistika. Bandung: Tarsito

Sugiyono, 2007, Statistika Untuk Penelitian. Bandung: ALFABETA.

Supranto, J. 2001, Pengukuran Tingkat Kepuasan Pelanggan : Untuk menaikkan pangsa pasar. Jakarta: PT. Rineka Cipta. 
Supranto, J 1997, Pengukuran tingkat Kepuasan Pelanggan Termasuk Analisis Tingkat Kepentingan dun Kinerja, dalam Usahawan, No. 5 Tahun XXVI Mei 1997.

Supraptono, Suryo, 1998, Analis Kualitas Pelayanan dan Kepuasan Pasien Rawat Inap RSUD, Dr.MURJANI, Universitas Gajah Mada.

Supriatna, Tjahya, 1993, Sistem Administrasi Pemerintahan di Daerah, cetakan I. Jakarta: Bumi Aksara.

Syafiie, Inu Kencana, Djamaluddin Tandjung, Supardan Modeong, 2004, "Ilmu Administrasi” Bisnaman Presindo.

Sylvana, A. 2006, "Pengaruh Kualitas Pelayanan Dan Kepuasan Mahasiswa Terhadap Intensi Meregistrasi Ulang Mahasiswa", "Jurnal Organisasi dan Manajemen", Volume 2, Nomor 1, Maret 2006, p. 60-78.

Tangklisan, Hessel Nogi S, 2003, Manajemen Modern untuk Sektor Publik, Jogyakarta: Balarairung.

Thoha, Miftah, 2003, Perpektif Perilaku Birokrasi. Dimensi-dimensi Prima Ilmu Administrasi Negara, Jakarta: PT. Radja Grafindo Persada.

Tjiptono, Fandy, 2002, Stategi Pemasaran, Jogyakarta: Penerbit Andi.

Tjiptono, Fandy, 2004, Pemasaran Jasa, Malang: Bayumedia.

Tjiptono, Fandy, 2007, Manajemen Jasa. Edisi Keempat, Yogyakarta: Andi Offet.

Tse, David K, and Willton, Piter, 1998, "Model of Custumer Service Formation, An Extension", "Journal of Makerting Research",Vol 25 May.

Umar, Husein, 2001, Riset Sumberdaya Manusia, Jakarta: PT. SUN.

Umar, Husein, 2005, Riset Sumber Daya Manusia Dalam Organisasi, Cetakan Ketiga, Jakarta: PT. Gramedia Pustaka Utama.

Umar, Husein, 2005, Evaluasi Kinerja Perusahaan, Jakarta: PT. Gramedia Pustaka Utama.

Wasistiono, Sadu, 2001, Kapita Selekta Manajemen Pemerintahan Daerah, Bandung: Alqaprint.

Wibowo. (2007). Manajemen Kinerja, Jakarta: PT. Raja Grafindo Persada.

Widayatun, Tri Rusmi, 1999, Ilmu Perilaku, Jakarta: Sagung Seto.

Widodo, 2001, Manajemen Stratejik, Jakarta: Bumi Aksara.

Wilkie, W.L, 1990, Customer Behavior, Edisi Kedua, New York: John Wiley \& Sons, Inc.

Willson and Heyyel, 1987, Hand Book Of Modern Office Management and Administration Service, New Jersey: Mc Graw Hill Inc.

Wirawan, 2009, Evaluasi Kinerja Sumber Daya Manusia, Jakarta: penerbit Salemba Empat.

Wungu, Jiwo, dan Hartanto Brotoharsojo, 2003, Tingkatan Kinerja Perusahaan, Jakarta: PT. Raja Grafindo Persada. 
Zeithaml, Valarie A, (et.al), 1990, Delivering Quality Services: Balancing Customer Perceptions and Expectations, New York: The Free Press, A Division of Macmillan Inc.

Kumpulan Peraturan Perundang - Undangan :

Undang-Undang Dasar 1945.

Undang-Undang Nomor : 12 Tahun 1995 Tentang Pemasyarakatan.

Undang-Undang Republik Indonesia Nomor 25 Tahun 2000 tentang Program Pembangunan Nasional (PROPENAS).

Undang-Undang Nomor : 5 Tahun 2014 Tentang Aparatus Sipil Negara.

Undang-Undang Nomor : 25 Tahun 2009 Tentang Pelayanan Publik.

Undang-Undang Nomor 43 Tahun 1999 tentang Perubahan atas Undang-Undang Nomor : 8 Tahun 1974 Tentang Pokok-Pokok Kepegawaian.

Peraturan Pemerintah Nomor : 96 Tahun 2012 Tentang Pelaksana Undang-Undang Nomor : 25 Tahun 2009 Tentang Pelayanan Publik.

Peraturan Pemerintah Nomor : 32 tahun 1999 Tentang Syarat dan Tata Cara Pelaksanaan Hak Warga Binaan Pemasyarakatan.

Peraturan Pemerintah Nomor : 46 tahun 2011 Tentang Penilaian Prestasi Kerja Pegawai Negeri Sipil.

Peraturan Pemerintah Nomor : 27 Tahun 1983 Tentang Pelaksana Kitab UndangUndang Hukum Acara Pidana.

Keputusan Menteri Pendayagunaan Aparatur Negara Nomor : 63/KEP/M.PAN/7/2003 Pelayanan Publik.

Keputusan Menteri Pendayagunaan Aparatur Negara Nomor : KEP/25/M.PAN/2/2004 tentang Pedoman Umum Penyusunan Indeks Kepuasan Masyarakat Unit Pelayanan Instansi Pemerintah.

Keputusan Menteri Pendayagunaan Aparatur Negara dan Reformasi Birokrasi Republik Indonesia Nomor : 16 Tahun 2014 tentang Survei Kepuasan Masyarakat.

Keputusan Menteri Kehakiman Nomor : M.01.PR.07.03. Tahun 1985 Tentang Organisasi dan Tata Kerja Lembaga Pemasyarakatan.

Keputusan Ketua LAN Nomor : 239/IX/6/8/2003, tanggal 23 maret 2003 Tentang Perbaikan Penyusunan Pelaporan Akuntabilitas Kinerja Instansi Pemerintah.

Peraturan Menteri Pendayagunaan Aparatur Negara dan Reformasi Birokrasi Republik Indonesia Nomor : 15 Tahun 2014 Tentang Pedoman Standar Pelayanan.

Surat Edaran Direktur Jenderal Pemasyarakatan Nomor : PAS-546.PK.01.04.06 Tahun 2014 Tentang Akses Pengaduan di Unit Pelaksana Teknis Pemasyaraktan.

Surat Edaran BKN Nomor : 02/SE/1980. Tentang Penilaian Pelaksanaan Pekerjaan Pegawai Negeri Sipil Tertanggal 11 Pebruari 1980. 
Surat Edaran Direktorat Jenderal Pemasyarakatan No. E.PS.01.06-16 Tanggal 23 Oktober 1996 tentang Penentuan Daya Muat/Kapasitas Lapas/Rutan/Cabang Rutan. 